\section{Mainstreaming Climate Change into Agricultural Education:}

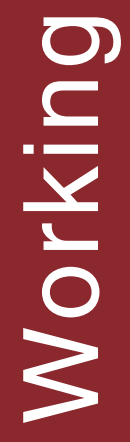

Challenges and Perspectives

Sebastian Chakeredza, August, B. Temu, Aissetou Yaye, Steven Makungwa, John, D.K. Saka 


\section{Mainstreaming Climate Change into Agricultural Education: Challenges and Perspectives}

Sebastian Chakeredza, August, B. Temu, Aissetou Yaye, Steven Makungwa, John, D.K. Saka
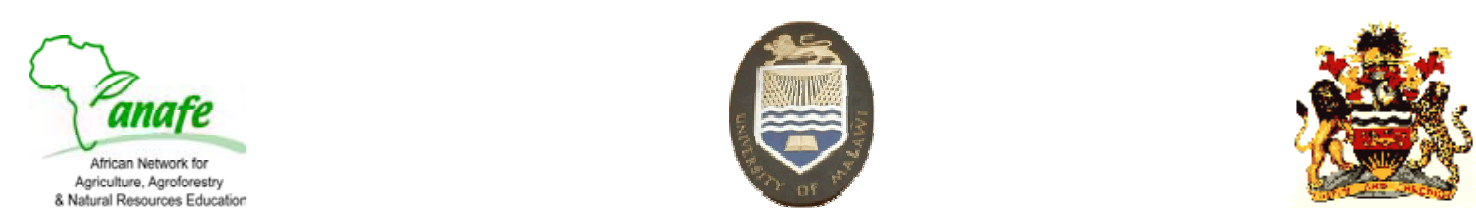


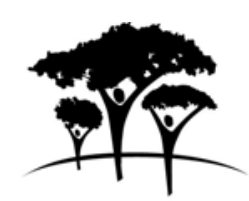

World Agroforestry Centre

TRANSFORMING LIVES AND LANDSCAPES

Correct citation: Chakeredza S, Temu AB, Yaye A, Mukingwa S, Saka JDK. 2009. Mainstreaming Climate Change into Agricultural Education: Challenges and Perspectives. ICRAF Working Paper no. 82. Nairobi, Kenya: World Agroforestry Centre.

Titles in the Working Paper Series aim to disseminate interim results on agroforestry research and practices and stimulate feedback from the scientific community. Other publication series from the World Agroforestry Centre include: Agroforestry Perspectives, Technical Manuals and Occasional Papers.

Published by the World Agroforestry Centre

United Nations Avenue

PO Box 30677, GPO 00100

Nairobi, Kenya

Tel: +254(0)20 7224000, via USA +1 6508336645

Fax: +254(0)20 7224001, via USA +1 6508336646

Email: icraf@cgiar.org

Internet: www.worldagroforestry.org

(C) World Agroforestry Centre 2009

ICRAF Working Paper no. 82

The views expressed in this publication are those of the author(s) and not necessarily those of the World Agroforestry Centre.

Articles appearing in this publication may be quoted or reproduced without charge, provided the source is acknowledged. No use of this publication may be made for resale or other commercial purposes.

All images remain the sole property of their source and may not be used for any purpose without written permission of the source. 


\section{Foreword}

Good education should provide solutions to development challenges. There is a strong positive correlation between levels of education and economic development in any given country. The major challenges facing humanity currently are associated with the negative effects of climate change, particularly in sub-Saharan Africa (SSA). Climate change is adversely affecting practically all economic sectors. Africa is projected to have a future associated with scarce water, declining agricultural yields, encroaching desert and damaged coastal infrastructure. The prognosis on the negative effects of climate change for SSA is therefore very grim.

It is gratifying to note that African educators themselves are taking a leading role in assessing what needs to be done for our educational institutions to make a significant contribution in providing solutions to the challenges posed by climate change. This Working Paper is an outcome of a symposium organized to share information on climate change challenges for agriculture in SSA; explore methods of mainstreaming climate change knowledge into agricultural education; and identify recommendations on effective policies, institutions and capacity.

The Working Paper lays down the key issues in climate change: who is affected and what direction we are taking if the negative effects presented by climate change are not checked. It presents a compelling argument on the role of tertiary education in making meaningful contributions and goes further to present a very reasonable action plan to be followed if we are going to keep on track with climate change adaptation and mitigation strategies.

The recommendations proposed in this Working Paper should be taken seriously by tertiary agricultural and natural resources management institutions in the whole of SSA and indeed governments in the sub-continent on mainstreaming climate change. Only if the educational institutions, in tandem with governments in Africa, take a leading role in combating the challenges posed by climate change to rural livelihoods, can we begin to see progress in this area.

The symposium was a first of its kind where tertiary agricultural and natural resources management institutions in SSA have taken a leading role in exploring mechanisms by which climate change can be integrated in our institutional curricula. I congratulate ANAFE and our educators for being pro-active and would like to take this opportunity to recommend that governments and development institutions provide all the necessary support to ensure that the implementation plan suggested in this Working Paper bears fruit.

\section{Professor Z.D. Kadzamira Vice Chancellor University of Malawi}




\section{Acknowledgements}

This Working Paper highlights the key outputs from the work presented by various scientists at the Climate Change Symposium of the African Network for Agriculture, Agroforestry and Natural Resources Education (ANAFE), held in Lilongwe from the 28 of July to the 1 of August, 2008. We are glad that so many scientists found the issue topical and were willing to make stimulating contributions. Over 100 participants from across sub-Saharan Africa and beyond participated in this symposium.

We are grateful that the University of Malawi through Bunda and Chancellor Colleges managed to host this symposium in Lilongwe. We thank the Organising Committee headed by Prof V.W. Saka of Bunda College, University of Malawi for working tirelessly to ensure that the symposium was a success.

We also thank our many sponsors including but not limited to the following: University of Malawi; ANAFE; ICRAF; CTA; FARA, ITOCA and UNDP for generously sponsoring the conference in various ways.

This Working Policy contains information which will remain a useful reference point for workers in the area of Climate Change. 


\title{
Acronyms and formulas
}

\author{
ANAFE \\ African Network for Agriculture, Agroforestry and Natural Resources \\ Education \\ $A U$ \\ CBD \\ African Union \\ Conservation of Biodiversity \\ CDM \\ CFC \\ Clean Development Mechanism \\ Chloro-fluoro carbon \\ CGIAR \\ $\mathrm{CH}_{4}$ \\ $\mathrm{CO}_{2}$ \\ COMESA \\ COP \\ CTA \\ ECOWAS \\ FAO \\ FARA \\ GDP \\ GHGs \\ ICRAF \\ IPCC \\ ITOCA \\ MEA \\ NAPA \\ NARI \\ NEPAD \\ NRM \\ $R \& D$ \\ REC \\ SADC \\ SASACID \\ SSA \\ TAE \\ UN \\ UNDP \\ UNFCCC \\ Consultative Group on International Agricultural Research \\ Methane \\ Carbon Dioxide \\ Common Market for Eastern and southern Africa \\ Conference of Parties \\ Technical Centre for Agriculture and Rural Cooperation, The Netherlands \\ Economic Community of West African States \\ Food and Agricultural Organisation \\ Forum for Agriculture Research in Africa \\ Gross Domestic Product \\ Greenhouse Gases \\ World Agroforestry Centre \\ Intergovernmental Panel on Climate Change \\ Information Training and Outreach Centre for Africa \\ Millennium Ecosystem Assessment \\ National Adaptation Plan of Action \\ National Agricultural Research Institute \\ New Partnership for Africa's Development \\ Natural Resources Management \\ Research and Development \\ Regional Economic Communities \\ Southern Africa Development Community \\ Strengthening Africa's Strategic Agriculture Capacity for Impact on \\ Development \\ sub-Saharan Africa \\ Tertiary Agricultural Education \\ United Nations \\ United Nations Development Programme \\ United Nations Framework Convention on Climate Change
}




\section{Contents}

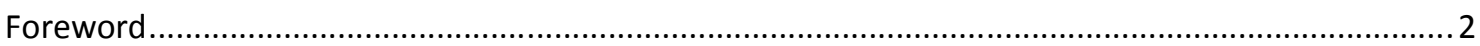

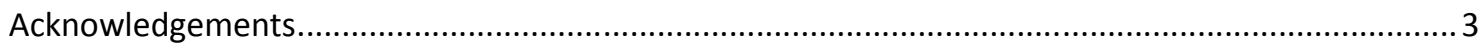

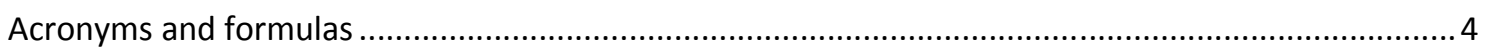

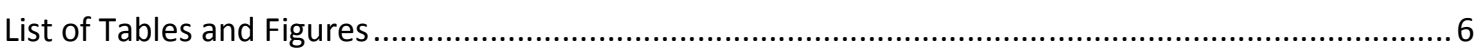

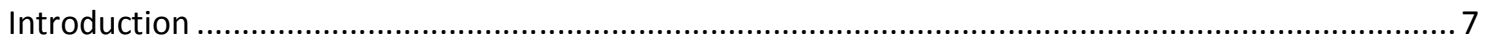

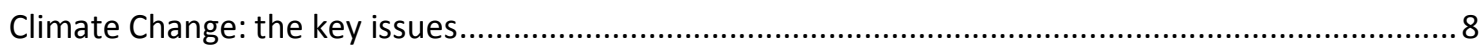

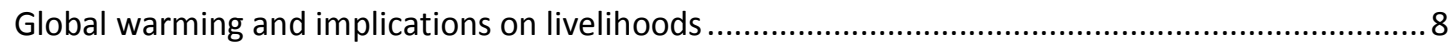

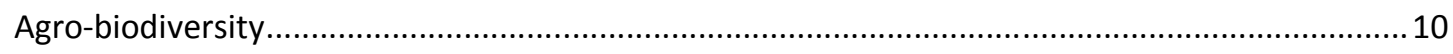

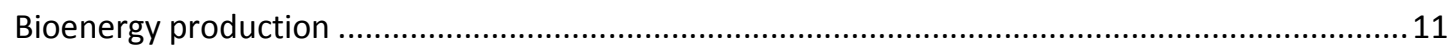

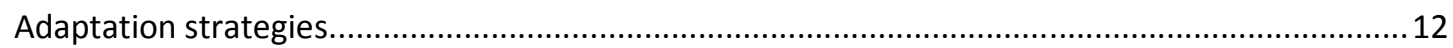

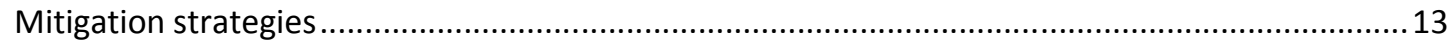

Status of climate change in agricultural higher education ............................................................... 14

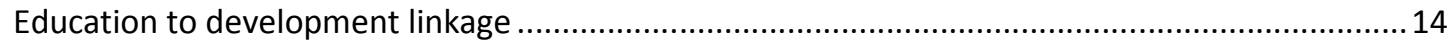

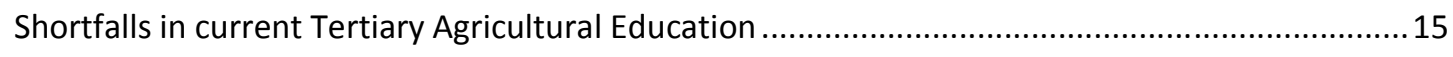

The need for climate change in the curricula ............................................................................ 16

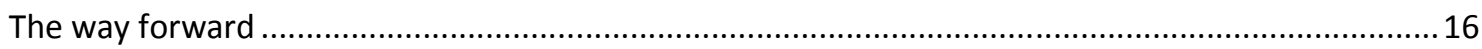

Implementation of global agreements relating to climate change ….............................................16

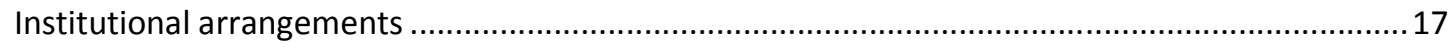

Integrating climate change into agricultural curricula............................................................... 18

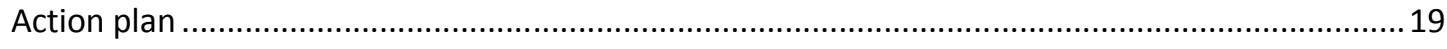

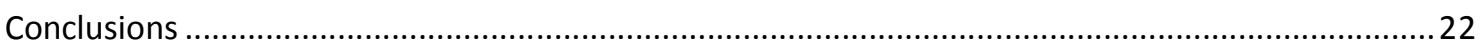

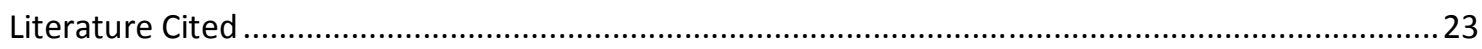




\section{List of Tables and Figures}

Table 1. International Institutions and Processes concerning climate change.................... 17

Table 2. Integrating climate change into the curriculum...................................................... 19

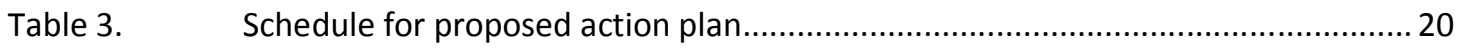

Figure 1. Greenhouse gas emissions in 2000, by source................................................. 8

Figure 2. Anthropogenic $\mathrm{CO}_{2}$ emissions by different countries/continents

from 1900-1999.

Figure 3. Responding to and influencing change; a model of the dynamic interaction between society and education..........................................................15

Figure 4. Framework for climate change institutionalisation in sub-Saharan

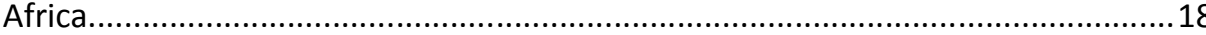




\section{Introduction}

Climate change is global in its causes and consequences. Through advanced modelling, patterns of change in the world climate have been observed over time. These model results have shown that compared to the pre-Industrial era, the world temperature has warmed by half a degree centigrade. The major causes for this warming have been attributed to the rising stocks of greenhouse gases in the atmosphere including carbon dioxide (CO2), methane ( $\mathrm{CH} 4)$, nitrous oxide (N2O), chloro-and fluoro-carbons and a number of other gases that arise from industrial processes. The current level or stock of greenhouse gases in the atmosphere is estimated to be equivalent to 430 parts per million (ppm) of carbon dioxide compared to 280 ppm before the industrial revolution (Stern, 2006). If we continue with business as usual, it is predicted that by the end of 2035 , there would be a $2^{\circ} \mathrm{C}$ increase in temperature. It is clear that climate change will impact heavily on agriculture and renewable natural resources. This means that our current practices may have to change significantly to adapt to and mitigate the changes.

It has long been perceived throughout the world, that Higher Education plays a critical role in preparing and providing the leadership to meet these challenges and to stimulate sustainable development (Bloom et al., 2005). In SSA, Higher Education in agriculture and natural resource management (NRM) in particular is well placed to contribute to this process.

Despite past investments by African governments in Higher Education, the hope that Universities would provide solutions to Africa's problems is yet to be realized. There has been an enormous loss through emigration of talented faculty to other continents. It is estimated that 23,000 qualified academic professionals emigrate from Africa each year in search of better working conditions (BASIC, 2006). Many of these are in agriculture and natural resources-areas that are of crucial economic importance for most African countries. In addition to these challenges, it is also accepted that the current curricula, teaching and learning methods are unsuitable for achieving the objectives of agricultural education.

The African network for Agriculture, Agroforestry and natural Resources (ANAFE) whose assigned mission is to improve the quality, relevance and application of tertiary agricultural education organized this symposium with the support of various partners.

The symposium objectives were to:

1. Understand the climate change challenges for agriculture in SSA

2. Discuss mechanisms for mainstreaming climate change knowledge into agricultural education and

3. Identify recommendations on effective policies, institutions and capacity.

One hundred participants comprising policy makers, financiers, educational managers and teachers at tertiary level in agriculture, forestry or NRM and those from agricultural research and industry participated in the symposium. Their thoughts on the issues of climate change and the associated issues of conservation of biodiversity and global shift towards bioenergy and how all these can be integrated in the curricula of tertiary agricultural institutions are contained in this Working Paper.

The purpose of this Working Paper is to inform, guide and support the development of responsive teaching programmes and capacity, and to stimulate more research to address climate change issues. Policy makers, education managers and the academia will need to establish a common platform for an integrated and coordinated response. Inter-sectoral cooperation and regional collaboration are also important. 


\section{Climate Change: the key issues Global warming and implications on livelihoods}

Climate change across the globe is real. The causes have now been documented and each day, the body of knowledge on the causes and consequences of climate change is being expanded. It is known that global warming which is the major cause of climate change is caused by the accumulation of greenhouse gases in the atmosphere (Saka, 2008). Figure 1 shows worldwide total emissions by industry in 2000 .

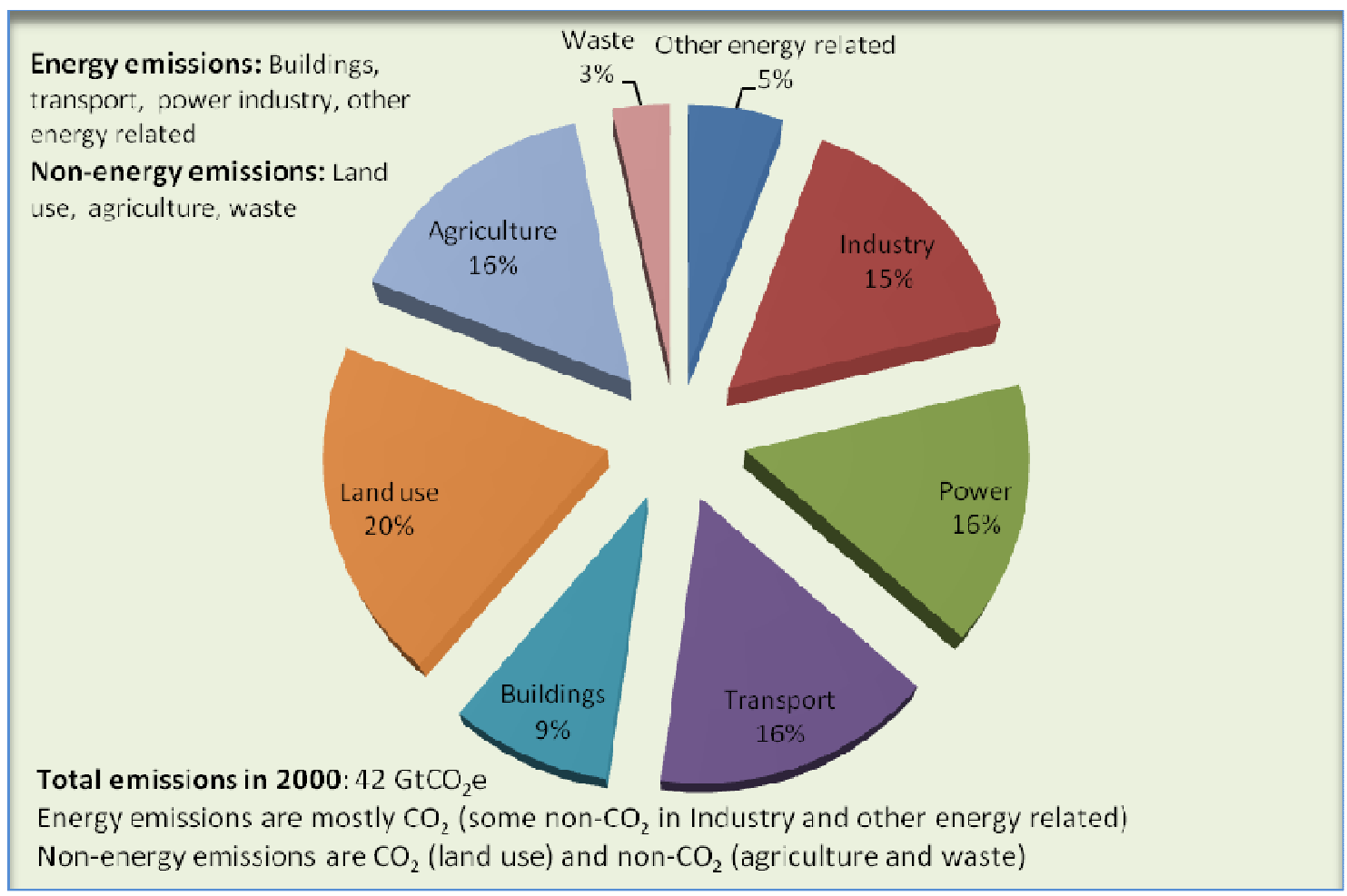

Figure 1. Greenhouse gas emissions in 2000, by source. Data adapted from Stern (2006)

With the current accelerating levels of emissions with fast-growing economies investing in high carbon infrastructure and as the demand for energy and transport increase, it is envisaged that there is between a 77-99 per cent chance that by about 2035, the world would have warmed by greater than $2^{\circ} \mathrm{C}$ (Stern, 2006). These changes are likely going to negatively impact on food production, health and the environment around the globe.

Over the 1900-1999 period, the emissions of anthropogenic $\mathrm{CO}_{2}$ from fossil fuel combustion show that Europe and the United States were the greatest contributors (Figure 2). 


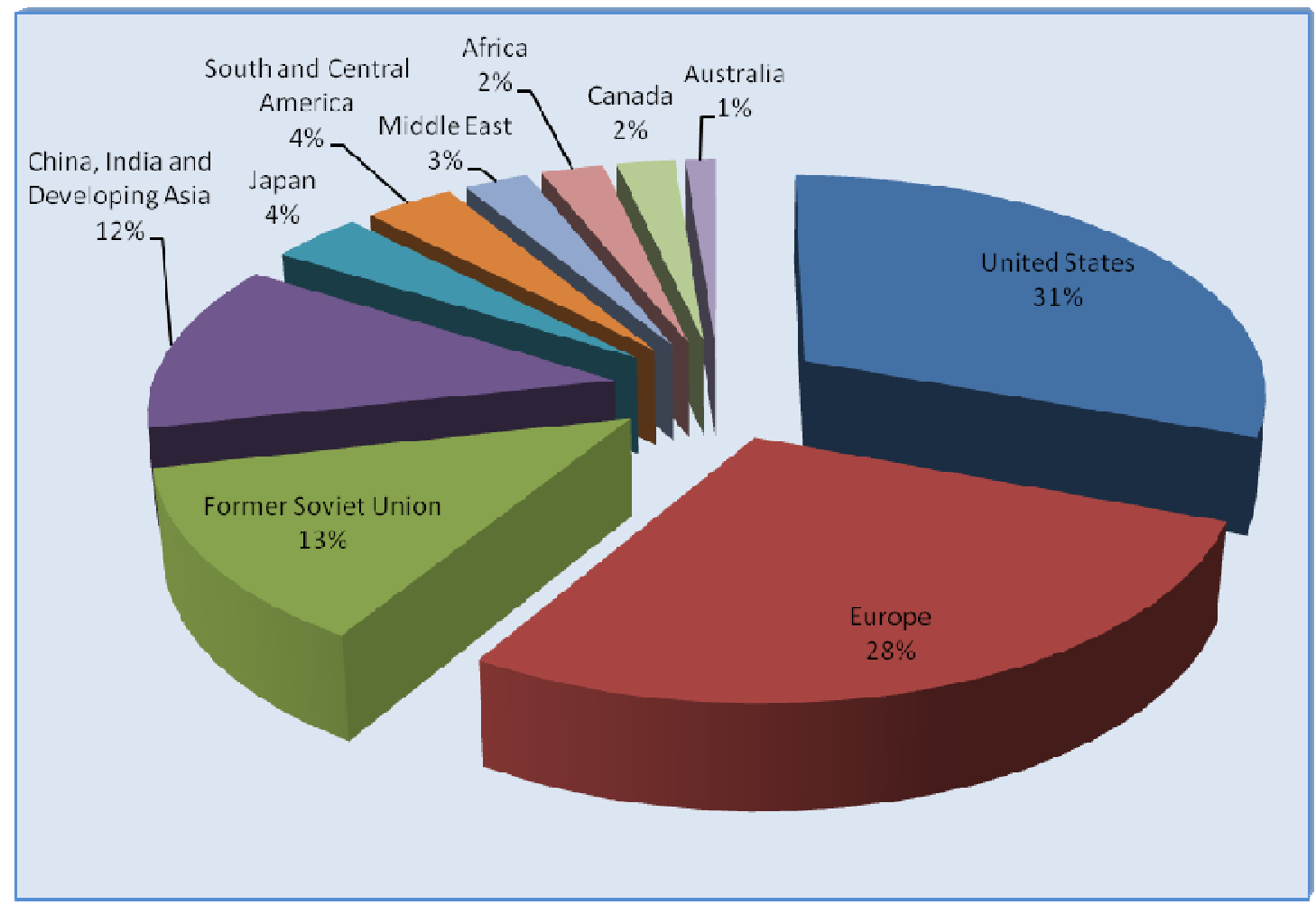

Figure 2. Anthropogenic $\mathrm{CO}_{2}$ emissions by different countries/continents from 1900-1999. (Data Source: Saka, 2008)

Africa's contribution of $2 \%$ is very small when compared with the industrialized countries. In any case, the major contributors are perhaps South Africa, Egypt and Nigeria. With increasing human activities, it is projected that greenhouse gas emissions will increase considerably over the coming years and by the year 2035, out of an estimated 11.7 billion tonnes of carbon that will be emitted, developed countries will contribute $50 \%$ and developing countries the other $50 \%$ (Saka, 2008). This significant shift in greenhouse gas (GHG) emissions has important implications for Africa and the world at large.

Warming may induce sudden shifts in regional weather patterns such as the El Niño phenomenon. These are changes that would have severe consequences for water availability and flooding in tropical regions and threaten the livelihoods of millions of people.

Most countries in SSA are already experiencing a number of adverse climatic hazards including dry spells, seasonal droughts, intense rainfall, riverine floods and flush floods. Some of these, especially droughts and floods have increased in frequency, intensity and magnitude over the last two decades, and have adversely impacted on food and water security, water quality, energy and the sustainable livelihoods of rural communities (Kandji et al., 2006).

Agriculture is a very important sector in the whole of SSA in terms of subsistence, contribution to Gross Domestic Product (GDP), employment and foreign exchange earnings (Diao et al., 2006). It is common knowledge that farmers in SSA, are struggling to cope with the current climate variability. With continued adverse climate change therefore, there will be decreased food production. It is predicted that the declining crop yields in SSA could leave hundreds of millions without the ability to produce or purchase sufficient food. 
In addition to the effects on food production, vector borne diseases such as malaria and dengue fever could become more widespread if effective control measures are not in place. This could increase the already negative impact of HIV/AIDS on food production. Rising sea levels will also result in tens to hundreds of millions more people flooded each year. Ecosystems and biodiversity will be particularly vulnerable to climate change, with around $15-40 \%$ of the species potentially facing extinction after only $2^{\circ} \mathrm{C}$ of warming. Ocean acidification, a direct result of the rise in $\mathrm{CO}_{2}$ will have major effects on marine ecosystems, with possible adverse effects on fish stocks.

We cannot continue with business as usual approach if we want to stabilise the GHGs. Stabilisation at whatever level requires that annual emissions be brought down to the level that balances the earth's natural capacity to remove greenhouse gases from the atmosphere. In the long term, annual global emissions will need to be reduced to below $5 \mathrm{GtCO}_{2} \mathrm{e}$ (gigatonnes of carbon dioxide equivalent emission), the level that the earth can absorb without adding to the concentration of the GHGs in the atmosphere.

Reversing the historical trend in emissions growth is a major challenge. Greenhouse-gas emissions can be cut in four ways:

- Reducing demand for emissions-intensive goods and services

- Increased efficiency which can save both money and emissions

- Action on non-energy emissions, such as avoiding deforestation and ecosystem degradation

- Switching to lower carbon technologies for power, heat and transport

Graduating students in tertiary agricultural institutions in SSA need to have a good grasp of the science of climate change, its effects on the livelihoods of the communities including the mitigation and adaptation options available for cutting the GHG emissions.

\section{Agro-biodiversity}

Agricultural biodiversity can be defined as: "the variety and variability of animals, plants and microorganisms, at the genetic, species and ecosystem levels, which are necessary to sustain key functions of an agricultural ecosystem, including its structure and processes" (adapted from CBD, 2000). Agrobiodiversity is central to human existence. It is the basis of humankind's ability to feed, clothe and heal itself. Farmers, rural communities and indigenous people around the world maintain the diversity of crop, forages, livestock, tree products and fish and the many other plant, animal and microbial species found in and around their production areas and depend on it to provide food, fuel, medicine and other products (Rudebjer et al., 2008). Thus biodiversity is recognized as a strong foundation for livelihood support and sustenance. Any threat to biodiversity will have impact on livelihoods.

The Millennium Ecosystem Assessment (MEA, 2005) has established that to meet demands for food, fresh water, timber, fibre and fuel, human activity in SSA has altered ecosystems. The report concludes that about $60 \%$ of the "ecosystem services" in SSA are being degraded or used unsustainably. These trends will present challenges and can be devastating for ecosystem function services and small-scale farmers in Africa because loss of agro-biodiversity results in the loss of many products which are used as part of farmers' livelihood strategies.

Climatic changes, in combination with other drivers, are expected to substantially alter agricultural biodiversity. At species level, biodiversity which is already endangered or vulnerable will face an increased extinction rate. There will also be a loss of intra-specific diversity and disappearance of marginal plant populations. This can be particularly serious for wild relatives of crops, which may 
contain valuable genes for plant breeding programmes for increasing heat and drought resistance or resistance to pests and diseases.

In 2007, Bioversity International commissioned a survey to evaluate how plant genetic resources and agro-biodiversity are being taught in universities in eastern and southern Africa (Muluvi et al., 2008 cited by Rudebjer et al., 2008). The countries surveyed included Kenya, Zimbabwe, Malawi, Zambia and Uganda. The results showed that none of the surveyed universities offered comprehensive agrobiodiversity programmes at undergraduate or graduate level. There is an urgent need to incorporate agrobiodiversity in the tertiary agricultural education programmes.

\section{Bioenergy production}

There is a drive worldwide to find alternative fossil fuels. This is in an effort to reduce carbon emissions and also to find new markets for agricultural products (Van Zyl et al., 2008). The major focus has been on the production of biofuels. By definition, a biofuel is any solid, liquid or gaseous fuel produced directly or indirectly from biomass, such as straw or grasses. Agro fuels are obtained as products of agriculture biomass, by-products of farming and or industrial processes of agriculture linked raw materials. The term covers mainly biomass materials derived directly from crops and agriculture, agro industrial and animal by-products such as dung, maize and soya. As a nearly carbon-neutral source of energy, most bio-energy systems can contribute to climate change mitigation through the carbon sequestration of bioenergy plantations. Agrofuels are made from sources which often represent major staples in Africa.

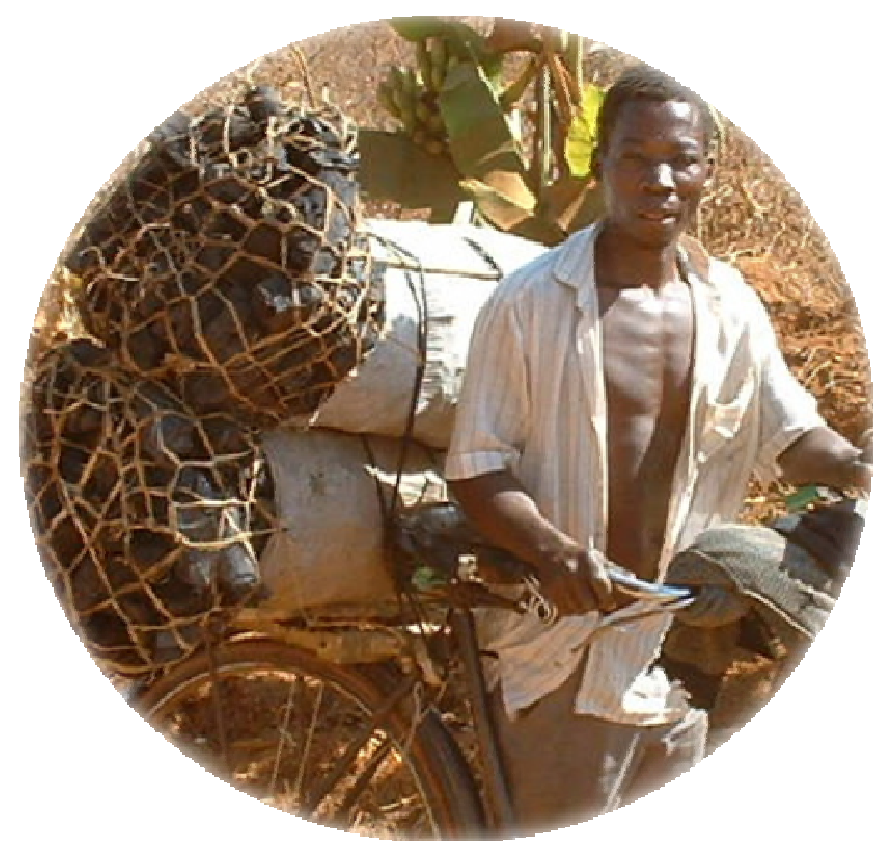

Charcoal production is causing irreparable damage to the environment

A current debate in SSA involves the extent to which the sub region should embrace biofuel production. It is projected that the production of agrofuels can lead to further clearing of land as well as the reduction of human food production. For instance, a $10 \%$ substitution of petrol and diesel is estimated to require $43 \%$ and $38 \%$ of current cropland area in the US and Europe, respectively. These figures are not likely to be different for SSA. Substitution at this level would require in addition to existing arable land, clearing of forests and grasslands. It is argued that clearing of forest would create a large upfront emissions cost that would outweigh the net reduction in carbon emissions from fossil fuels. Jatropha (Jatropha curcas), a widely acclaimed biofuel crop touted as ideal for growth on "degraded land" is widely considered a weed and is potentially an invasive species. Experts must assess ecological risks before introducing biofuel crops.

There is a need for SSA governments to approach the issue of biofuels cautiously (Jumbe and Msiska, 2008). It is recommended that SSA needs to: 
- Develop comprehensive national biofuels policies and plans in consultation with stakeholders including regional economic communities (RECS) such as SADC, ECOWAS, and COMESA, and with AU/NEPAD;

- Make wise selection of biofuel species and develop appropriate agronomic standards for guaranteed productivity, profitability and with minimal negative effects,

- Raise the resources for infrastructural development for production, processing, storage, transporting and marketing of biofuels products,

- Commit resources for research and development (R\&D), capacity-building and technical support, and

- Establish regulatory and institutional frameworks that provide the incentives for private sector participation in the development of the biofuel industry.

Bioenergy is a new area which integrates different disciplines. There is a need to integrate Bioenergy into agricultural learning so that graduating students appreciate its socio-economic role in the livelihoods of communities in SSA.

\section{Adaptation strategies}

To deal with the negative effects of climate change there are a number of adaptation strategies that can be adopted in different situations. Adaptation to climate change is a process through which people reduce the adverse effects of climate on their health and well-being and take advantage of opportunities that the environment provides. Saka (2008) notes that adaptation measures to climate change among communities have been considered with two broad activities in mind: i) measures that reduce vulnerability and ii) Measures that increase resilience through the utilization of the available common assets.

At the national level, there is a need to implement policies and strategies that avert the undesirable effects and impact of climate change on different sectors of economic growth. At local farm level, these can be distinguished for the crops, forestry and livestock sub-sectors. Changes in land-use and changes in crop and livestock management strategies will have to take place. Examples include a) changes in cultivated land area, b) changes in crop types, c) growing crop species or varieties with higher thermal requirements or those that are tolerant to drought and floods, d) changes in crop location, e) intensive and extensive use of irrigation water and improved fertilizer use efficiency to counter the effects of droughts, periodic water stress and low soil fertility conditions, f) control of insect pests and diseases associated with floods and droughts, g) improvements in soil management practices to reduce surface runoff and soil erosion h) establishment and creation of food grain reserves at farm and community levels for safe-keeping and storage of harvested produce, and i) diversifying species and intercropping crops with trees to benefit from improved micro-climate and tree products and services. These adaptation strategies need to be taken in tandem with government policies and strategies of poverty alleviation and food security. 
A number of organisations worldwide, for example FAO are promoting the use of indigenous and locally adapted plants and animals as well as the selection and multiplication of crop varieties adapted or resistant to adverse conditions. The selection of crops and cultivars with tolerance to abiotic stresses (e.g. high temperatures, drought, flooding, high salt content in soil, pest and diseases) allows harnessing genetic variability in new crop varieties. National programmes should have capacity built and long-term support to use these options.

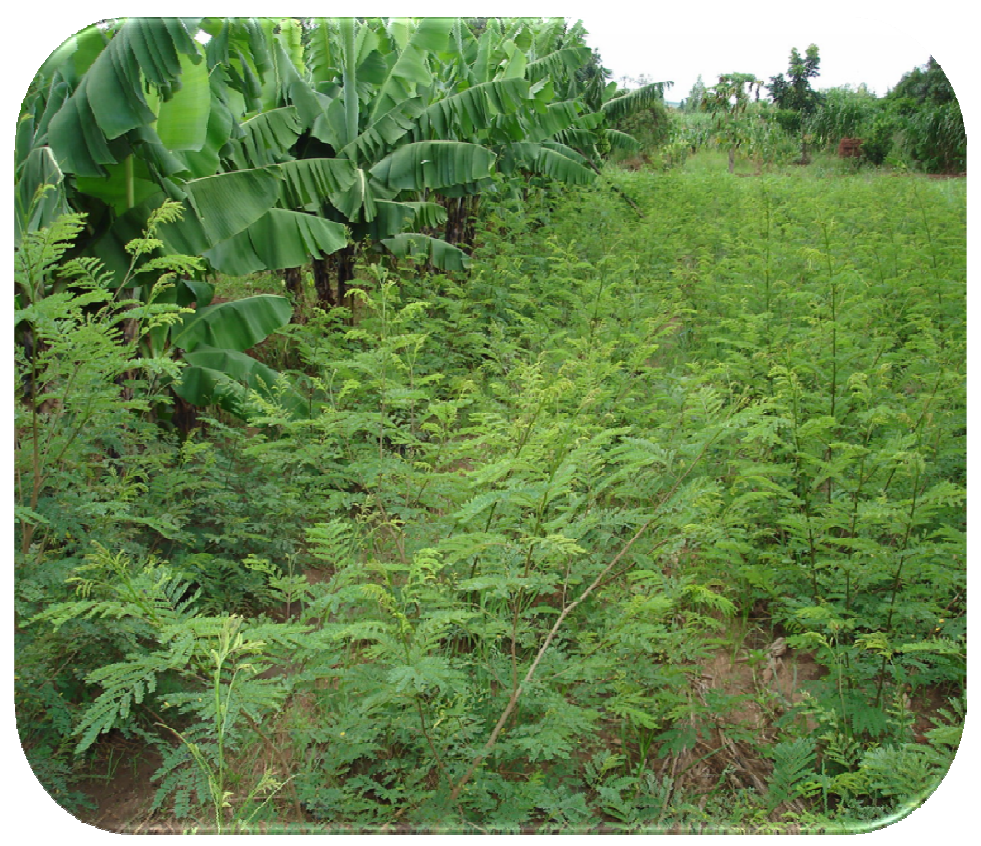

Agroforestry can enhance adaptation to climate change through provision of diversified tree products and services

\section{Mitigation strategies}

Since it has been demonstrated that GHG emissions resulting from man's activities are responsible for global warming and subsequent changes in the climate system, there is a need to identify measures for limiting greenhouse gas emissions into the atmosphere. There is a need to use cleaner technologies that do not emit a lot of GHGs or provide sinks for the emitted GHGs. Most of the mitigation measures will be in the energy sector through use of cleaner technologies, forestry sector through reafforestation and the agriculture sector through improved fertilizer application, crop and livestock management.

In the forestry sector strategies include planting of tree species in woodlots, forestry plantations, onfarm boundary planting and other agroforestry systems. In the energy sector, strategies would include biomass-based technologies such as use of i) wood fuel in improved mud stoves and ceramics, ii) biogas fuel from bio-wastes to produce biogas for cooking and heating, and iii) briquettes for cooking instead of wood. The non-biomass based strategies would include i) rural electrification through grid extension, ii) mini-hydropower, iii) compact fluorescent lamps for lighting, iv) renewable energy sources (solar cookers and heaters) and v) wind power for pumping water.

For the agriculture sector, strategies to reduce the GHG emissions include: i) incorporation of crop residues into the soil instead of burning, ii) good management of livestock manure to reduce methane emissions and proper management of nitrogenous fertilizers in rice and upland agricultural soils to reduce nitrous oxide emissions. 
Some scientists think mitigation of climate change needs a more radical approach. The Royal Society Academy in England has written a series of papers in "Philosophical Transactions" proposing "geoengineering" as a way of buying time for the transition to a low-carbon economy to take place in an orderly manner (Schneider, 2008). Broadly the ideas fall into two categories: one is to remove excess $\mathrm{CO}_{2}$ from the atmosphere while the other is to compensate for climate-warming greenhouse effects the $\mathrm{CO}_{2}$ and other gases cause, by reducing the amount of sunlight reaching the ground. The strategies include increasing photosynthesis to wipe out excess $\mathrm{CO}_{2}$ through planting more trees and also through encouraging increased phytoplankton growth which eventually will sink to the bottom of the ocean and not release the carbon. The $\mathrm{CO}_{2}$ can also be recycled into fuel through a reaction with $\mathrm{H}_{2}$ or it can be ejected from the atmosphere using the planet's magnetic field. The stratosphere can also be deliberately polluted with sulphate in order to reflect solar heat into space. These ideas are all being tested and if they can be proven to be satisfactory, with predictable long-term effects, they could offer mankind the space and opportunity to think through more sustainable mitigation strategies to the challenges posed by climate change.

It will be important that students in tertiary agricultural institutions have a good understanding of the issues surrounding climate change mitigation and the new concept of geoengineering.

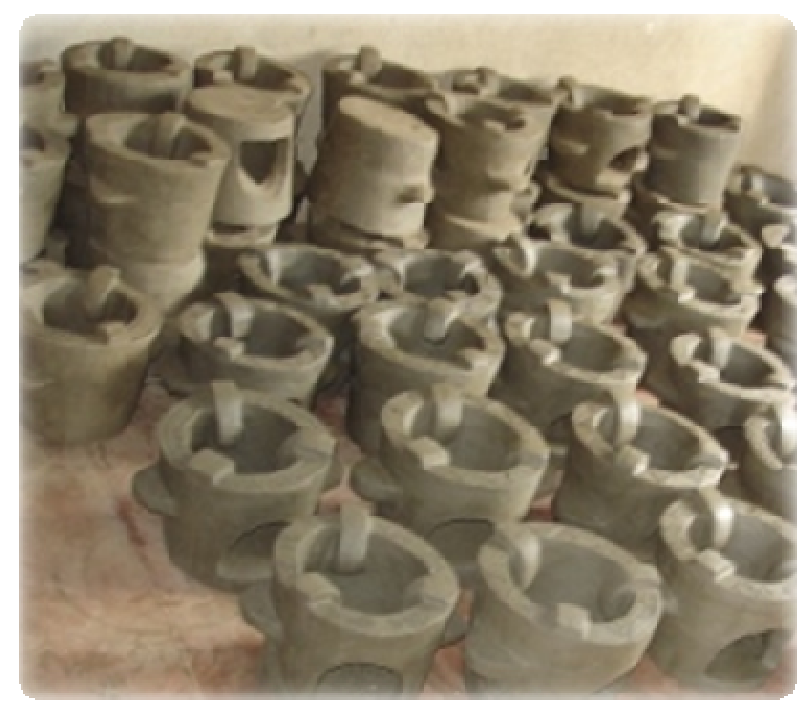

Fuel efficient stoves are being promoted to reduce the rate of deforestation

\section{Status of climate change in agricultural higher education Education to development linkage}

Temu et al. (2003) describes the linkage between education and society. Education can be described as the process of preparing an individual to become a functional and acceptable member of society. Two concepts are inbuilt in the definition of education, namely: creation of knowledge and experience, and growth and development. Unless tertiary agricultural education (TAE) is able to respond to societal challenges and expectations, society will also have difficulties in understanding the roles of TAE (Figure 3). 
How education influences society:

- Graduates gain employment

- Lecturers research, conduct outreach and participate in public debate

\section{Educational Change}

Changes related to the teaching and learning process, its tools and institutions:

-Institutional innovation

- Curricula content

- Teaching materials

- Teaching and learning methods

- Delivery capacity (human

resources and learning facilities)
Societal Change

Local, national and long-term

Global trends

-Poverty alleviation

-Agriculture and rural

development

-Economic growth

-Demographic change

-Environmental change

-Global conventions, Millennium

Development Goals and so on

How society influences education:

- Graduates gain employment

- Lecturers research, conduct outreach and participate in public debate

Figure 3. Responding to and influencing change; a model of the dynamic interaction between society and education. Source: Rudebjer et al. (2005).

Society is today presented with climate change challenges. If education is going to make a contribution to the current challenge then there should be institutional innovations and changes to ensure that graduates produced from the tertiary agricultural institutions are abreast with the climate change issues including mitigation and adaptation strategies. The curricular content, teaching materials and methods and delivery approaches should be designed in such a way as to equip the student with the necessary skills and knowledge to tackle these global challenges and their interpretation in specific local situations. ANAFE has noted that learning materials are generally not adequately contextualised in the local African environment. This is true for many agricultural subjects and for climate change. This implies that the tertiary education institutions are not responding adequately to societal challenges.

\section{Shortfalls in current Tertiary Agricultural Education}

The shortfalls in tertiary agricultural education have been described by for example by Temu et al. (2003) and Chakeredza et al. (2008). Against the background of the current brain drain, it is observed that among other problems, the major constraints in tertiary agricultural education are as follows:

- Poor staffing of institutions to meet the desired curriculum coverage

- The training is predominantly based on curricula adopted from countries that had colonies in Africa. The curricula were founded on an agricultural philosophy that aimed at the production of cash crops for consumption by the colonising countries. 
- Teaching mode is not learner-centred

- There is very little interaction with farming communities. In fact, most of the universities are located in towns where there are no farming communities to work with nearby. In most cases the farming community is not involved in the design and delivery of agricultural curricula, and

- There is absence of Private Sector involvement in the design and delivery of agricultural curricula

As a result, it is not surprising that SSA tertiary agricultural institutions have so far done very little in the integration of climate change issues into tertiary agricultural education. There is a need to rethink and transform the tertiary agricultural education system so that it becomes responsive to the needs of the society. From the ANAFE symposium of 2003, Temu et al. (2003) suggested a framework which could be followed to address shortfalls in tertiary agricultural institutions. The findings and recommendations are still relevant today as they were in 2003 and need to be addressed as we move into the future. Through its network of universities, ANAFE has further developed a new programme dubbed SASACID (Strengthening Africa's Strategic Agricultural Capacity for Impact on Development). This visionary programme addresses all the major key weaknesses in African agricultural education (http://www.anafeafrica.org). The challenge is for countries to play their roles in the transformative programme.

\section{The need for climate change in the curricula}

Increasingly, climate change is becoming a challenge to agricultural production because it increases risks and uncertainties for farmers. There is a need for graduating agricultural students to be wellversed with the challenges posed by climate change if they are going to advise the communities they will be working with appropriately. They also need to understand the implications of climate change to economic development and international trade.

Educating those currently at school about climate change will help to shape and sustain future policy-making. Studies on climate change have so far been limited to adaptation and mitigation intervention strategies. Faculty and students should be able to contribute to the development of the body of knowledge as regards climate change.

Students should be aware of the various International Conventions and Protocols surrounding climate change. These include UN Framework convention on climate change (UNFCCC), Kyoto protocol and a range of other informal partnerships and dialogues that provide a framework that supports co-operation, and a foundation from which to build further collective action. The challenges are to develop good curricula, produce relevant learning resources and capacitate educators.

\section{The way forward}

\section{Implementation of global agreements relating to climate change}

The world needs to cooperate if climate change challenges are going to be addressed. In 1992, many countries signed the United Nations Framework Convention on Climate Change (UNFCCC) which obliges parties to periodically update and publish inventories of anthropogenic emissions of all GHGs. The aim of the UNFCCC is to stabilise GHG concentrations in the atmosphere at a level that would prevent dangerous human-induced interferences with the climate system. This information is communicated to the Conference of Parties (COP) in the form of "National Communications" based on five broad considerations: i) National circumstances/context, ii) National GHG inventory, iii) 
Vulnerability and adaptation assessments, iv) Greenhouse gas mitigation and abatement analyses and v) Constraints and gaps and related financial, technical and capacity needs. Further, concerted efforts are needed to mainstream climate change into various sectoral policies, strategies and programmes, including agricultural education at all levels of learning.

It is also clear that many conventions, agreements and protocols have aspects relating to climate change. In Table 1 we present some of the more important and related conventions and their main functions.

Table 1. International Institutions and Processes concerning climate change

\begin{tabular}{|c|c|}
\hline Convention & Functions \\
\hline $\begin{array}{l}\text { IPCC, Intergovernmental } \\
\text { Panel on Climate Change }\end{array}$ & $\begin{array}{l}\text { Puts together data concerning climate change and guides UN actions and } \\
\text { negotiation processes. }\end{array}$ \\
\hline $\begin{array}{l}\text { UNFCCC, United Nations } \\
\text { Framework Convention on } \\
\text { Climate Change (1992) }\end{array}$ & The UNFCCC provides a framework for policy to deal with climate change. \\
\hline Kyoto Protocol (1997) & $\begin{array}{l}\text { Highlights adoption of climate change convention and specific commitments } \\
\text { developed by individual countries. It deals with reduction of greenhouse gas } \\
\text { emissions from developed countries through non-domestic sources. } \\
\text { Development of mechanisms for carbon trading and joint implementation } \\
\text { activities. Also highlights adoption of climate change conventions and specific } \\
\text { commitments by countries. }\end{array}$ \\
\hline COP, Conference of Parties & $\begin{array}{l}\text { Convenes meetings of stakeholders with interest to implement mitigation and } \\
\text { adaptation activities. COP } 1 \text { up to } 11 \text { have been conducted. COP is interested } \\
\text { in institution structures and financial mechanisms including social networks, } \\
\text { and access to resources. Has particular interest on climate change impact on } \\
\text { the rural poor, particularly looking at ways of reducing environmental risk, } \\
\text { strengthening of livelihood activities and minimizing stress to social } \\
\text { institutions. }\end{array}$ \\
\hline $\begin{array}{l}\text { CDM, Clean Development } \\
\text { Mechanism }\end{array}$ & $\begin{array}{l}\text { This was created by the Kyoto Protocol as the formal channel for supporting } \\
\text { low-carbon investment in developing countries. It allows for both } \\
\text { governments and private sector to invest in projects that reduce emissions in } \\
\text { fast-growing emerging economies and provides one way to support links } \\
\text { between different regional emissions trading schemes. }\end{array}$ \\
\hline UN adaptation fund & $\begin{array}{l}\text { Created under the UNFCCC, this is an instrument under the Global } \\
\text { Environmental Facility to assist developing countries to adapt to climate } \\
\text { change }\end{array}$ \\
\hline
\end{tabular}

Source: Temu and Chakeredza (2008)

There is a need to ensure that these protocols are enforced and the agreements are binding. Within each country there is a need for a common system for supporting and monitoring implementation.

\section{Institutional arrangements}

There is a need to identify the key players at country level regarding climate change knowledge management issues. The key issues identified at the symposium include: knowledge management (research, education, collating, synthesising and sharing lessons); Policy and international dialogue; National Planning and Financing; and Local level implementation. The key issues under each area are presented in Figure 4. There is also a need to ensure coordination, synergy and regional collaboration on climate change education and research. 


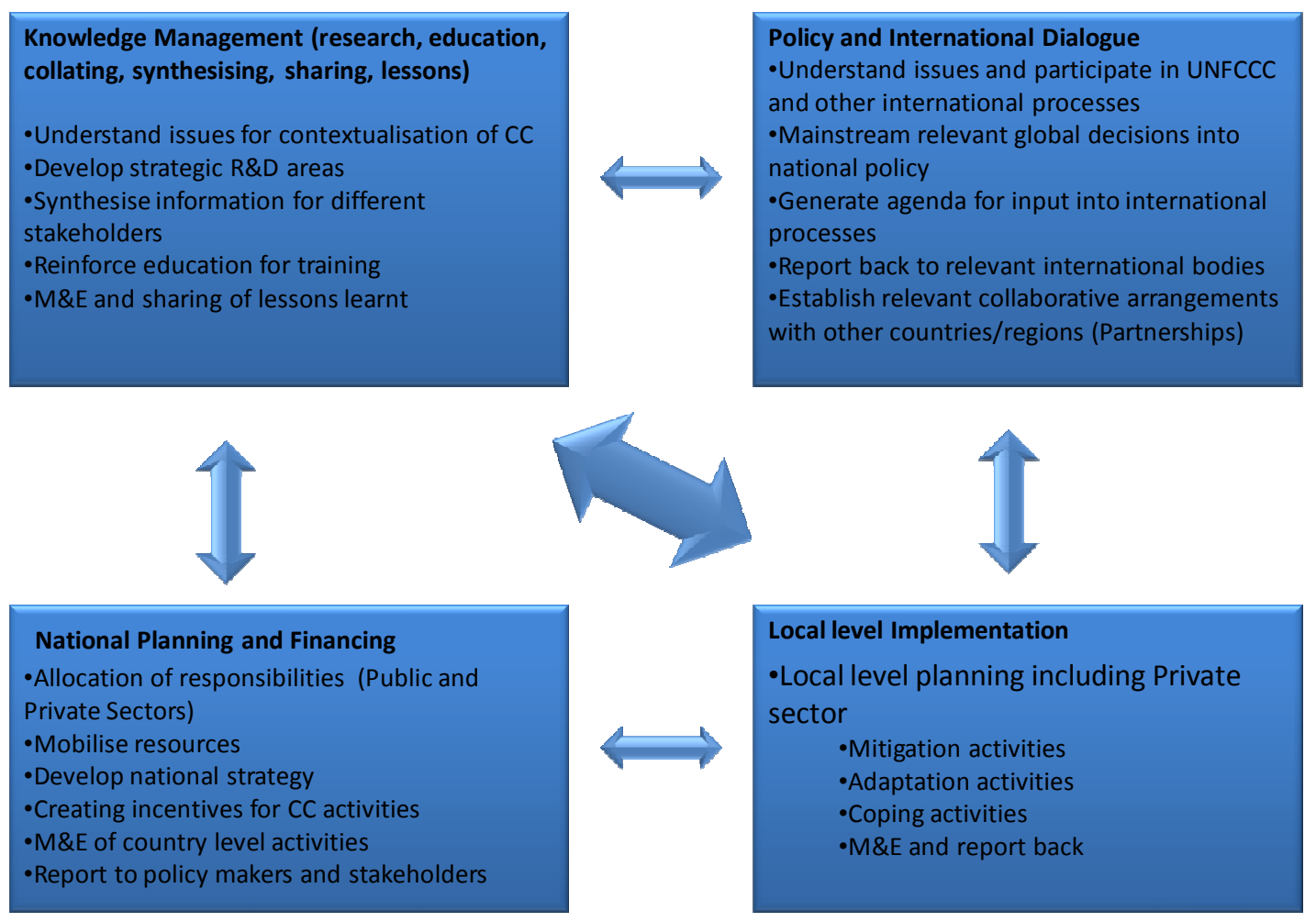

CC, climate change; M\&E, Monitoring and evaluation; R\&D, Research and development; UNFCCC, United Nations Framework Convention on Climate Change.

Figure 4. Framework for climate change Institutionalisation in SSA

Source: Temu and Chakeredza (2008)

\section{Integrating climate change into agricultural curricula}

Climate Change should be integrated into the curricula of tertiary agricultural institutions as a matter of urgency. There is need for concrete scientific data based on African experiences to be infused into the curricula. The suggested areas of emphasis are as presented in Table 2. The curricula can be handled as a separate subject or infused and integrated into the various agricultural and natural resources management subjects. The recommended teaching and learning methods should be lectures (including guest lectures), seminars, group discussions, visits to sites demonstrating the impact of climate change and or adaptation and mitigation work in progress, on-farm discussions and surveys. eLearning enhanced with research repositories can also be pursued where possible.

Disciplines could also be selected with the greatest potential to deliver on mainstreaming climate change into tertiary agricultural and natural resources management education. The objective will be to ensure that graduating students in agriculture and natural resources management fully understand and grasp the implications of climate change on the whole global economy. The thrust should be towards building a cadre of academics and researchers with appropriate knowledge and skills on the key issues affecting society and be in a position to advise policy makers, educational establishments and practitioners. 
Table 2. Integrating climate change into the curriculum

\begin{tabular}{|l|l|}
\hline Area & Aspects to be covered \\
\hline Introduction to Climate change & $\begin{array}{l}\text { Implications of climate change to people's livelihoods and the } \\
\text { world economy. }\end{array}$ \\
\hline Agrobiodiversity & $\begin{array}{l}\text { The causes of global warming and projections under different } \\
\text { scenarios. }\end{array}$ \\
\hline Biofuels & $\begin{array}{l}\text { The need to maintain agrobiodiversity under climate change } \\
\text { threat; Impact of land use change on agrobiodiversity at } \\
\text { ecosystems, species and within-species levels; Adaptation to } \\
\text { climate change: agrobiodiversity options; Approaches for putting } \\
\text { adaptation strategies into practice in research, extension and } \\
\text { policy implementation. }\end{array}$ \\
\hline Adaptation Strategies & $\begin{array}{l}\text { The need for reduced carbon emissions. Alternative fuel } \\
\text { production with special focus on biofuels. Socio-economic } \\
\text { implications. }\end{array}$ \\
\hline Mitigation Strategies & $\begin{array}{l}\text { Options available to adapt to the adverse effect of climate change } \\
\text { by different groups of people. }\end{array}$ \\
\hline $\begin{array}{l}\text { Global policy issues on climate } \\
\text { change }\end{array}$ & $\begin{array}{l}\text { Reduction of carbon emissions; Geo-engineering concepts and } \\
\text { practices }\end{array}$ \\
\hline
\end{tabular}

CDM, Clean Development Mechanism; NAPA, National Adaptation Plan of Action; UNFCCC, United Nations Framework Convention on Climate Change.

\section{Action plan}

The symposium participants formulated an action plan detailing what needs to be done, when and by who to address the key issues raised. These are elaborated in Table 3 by subtheme. It will be important that all key institutions in SSA are brought on board to champion this implementation framework plan suggested at the symposium.

- Coping with climate change and building the capacity to compete globally

- Conservation of biodiversity and sustainable agricultural production

- Global shift towards bioenergy production and

- Effective agricultural institutions 
Table 3. Schedule for proposed action plan

\begin{tabular}{|c|c|c|c|}
\hline nmended Actions & When $^{1}$ & Responsibility & Commel \\
\hline \multicolumn{4}{|c|}{ Coping with climate change and building the capacity to compete globally } \\
\hline $\begin{array}{l}\text { Develop and adjust policies at all } \\
\text { levels to ensure that climate change } \\
\text { is integrated in tertiary agricultural } \\
\text { education }\end{array}$ & $\begin{array}{l}\text { Short } \\
\text { term }\end{array}$ & $\begin{array}{l}\text { Policy makers at the local, country } \\
\text { and regional levels; Universities } \\
\text { and Colleges teaching agriculture } \\
\text { and NRM }\end{array}$ & $\begin{array}{l}\text { A significant develo } \\
\text { will place the clim } \\
\text { agenda into proper c }\end{array}$ \\
\hline $\begin{array}{l}\text { Develop climate change curricula to } \\
\text { be offered either as a standalone } \\
\text { course or integrated within other } \\
\text { courses }\end{array}$ & $\begin{array}{l}\text { Medium } \\
\text { term }\end{array}$ & $\begin{array}{l}\text { niversities and Colleges teaching } \\
\text { griculture and NRM }\end{array}$ & $\begin{array}{l}\text { urse } \\
\text { with } \\
\text { e }\end{array}$ \\
\hline $\begin{array}{l}\text { Support educators to develop } \\
\text { relevant teaching materials in } \\
\text { climate change }\end{array}$ & $\begin{array}{l}\text { Medium } \\
\text { term }\end{array}$ & $\begin{array}{l}\text { Universities and Colleges teaching } \\
\text { agriculture and NRM; Investors; } \\
\text { NARIs; CGIAR. }\end{array}$ & \\
\hline $\begin{array}{l}\text { Promote research to enhance the } \\
\text { knowledge base on climate change }\end{array}$ & $\begin{array}{l}\text { Medium } \\
\text { to long } \\
\text { term }\end{array}$ & $\begin{array}{l}\text { Universities and Colleges teaching } \\
\text { agriculture and NRM, Private } \\
\text { Sector, Investors }\end{array}$ & $\begin{array}{l}\text { n climate } \\
\text { ontinually }\end{array}$ \\
\hline $\begin{array}{l}\text { Promote collaborative research } \\
\text { projects for enhanced agricultural } \\
\text { productivity in SSA }\end{array}$ & $\begin{array}{l}\text { Medium } \\
\text { to long } \\
\text { term }\end{array}$ & $\begin{array}{l}\text { Universities and Colleges teaching } \\
\text { agriculture and NRM; CGIAR, } \\
\text { Investors; NARIs. }\end{array}$ & $\begin{array}{l}\text { lation on } \\
\text { can be } \\
\text { scale }\end{array}$ \\
\hline \multicolumn{4}{|c|}{ Conservation of biodiversity and sustainable agricultural production } \\
\hline $\begin{array}{l}\text { Adjust policies at all lev } \\
\text { into account the impo } \\
\text { agro-biodiversity for } 5 \\
\text { agricultural production in }\end{array}$ & $\begin{array}{l}\text { Short } \\
\text { term }\end{array}$ & $\begin{array}{l}\text { sional levels; Univ } \\
\text { leges teaching agri } \\
1\end{array}$ & $\begin{array}{l}\text { Will place into perspective } \\
\text { options for future sustainable } \\
\text { agricultural production }\end{array}$ \\
\hline $\begin{array}{l}\text { Integrat } \\
\text { develop }\end{array}$ & $\mathrm{n}$ & RM & $\begin{array}{l}\text { diversity } \\
\text { hallenges } \\
\text { e }\end{array}$ \\
\hline $\begin{array}{l}\text { Support educators to develop } \\
\text { climate change curricula that } \\
\text { integrates agro-biodiversity }\end{array}$ & $\begin{array}{l}\text { Medium } \\
\text { term }\end{array}$ & $\begin{array}{l}\text { and N } \\
\text { estors; NAR }\end{array}$ & $\begin{array}{l}\text { This will form the basis for } \\
\text { course delivery }\end{array}$ \\
\hline $\begin{array}{l}\text { Promote research that maximises } \\
\text { the contribution of agro- } \\
\text { biodiversity to sustainable } \\
\text { agricultural production in SSA }\end{array}$ & $\begin{array}{l}\text { Medium } \\
\text { to long } \\
\text { term }\end{array}$ & $\begin{array}{l}\text { Universities and Colleges teaching } \\
\text { agriculture and NRM; CGIAR, } \\
\text { Investors }\end{array}$ & $\begin{array}{l}\text { base on use and } \\
\text { agrobiodiversity } \\
\text { d }\end{array}$ \\
\hline \multicolumn{4}{|c|}{ Global shift towards bioenergy production } \\
\hline $\begin{array}{l}\text { Develop policies that take into } \\
\text { account the mitigatory role to } \\
\text { climate change and socio-economic } \\
\text { impact of bioenergy production }\end{array}$ & $\begin{array}{l}\text { Short } \\
\text { term }\end{array}$ & $\begin{array}{l}\text { Policy makers at the local, country } \\
\text { and regional levels; Universities } \\
\text { and Colleges teaching agriculture } \\
\text { and NRM }\end{array}$ & $\begin{array}{l}\text { Will place into perspective the } \\
\text { biofuel option for mitigation } \\
\text { climate change and for } \\
\text { improved livelihoods }\end{array}$ \\
\hline $\begin{array}{l}\text { Integrate bioenergy production into } \\
\text { the developed climate change } \\
\text { curricula }\end{array}$ & $\begin{array}{l}\text { Medium } \\
\text { term }\end{array}$ & $\begin{array}{l}\text { es and Colleges teaching } \\
\text { e and NRM }\end{array}$ & $\begin{array}{l}\text { biofuel given climate } \\
\text { llenges will be given }\end{array}$ \\
\hline $\begin{array}{l}\text { Support educators to develop } \\
\text { climate change curricula that } \\
\text { integrates bioenergy production }\end{array}$ & $\begin{array}{l}\text { Medium } \\
\text { term }\end{array}$ & $\begin{array}{l}\text { ies and Colleges teaching } \\
\text { re and NRM, Private } \\
\text { vestors; NARIs; CGIAR. }\end{array}$ & $\begin{array}{l}\text { This will form the basis for } \\
\text { course delivery }\end{array}$ \\
\hline $\begin{array}{l}\text { Promote research that maximises } \\
\text { the contribution of bioenergy } \\
\text { production taking into account the }\end{array}$ & $\begin{array}{l}\text { Medium } \\
\text { to long } \\
\text { term }\end{array}$ & $\begin{array}{l}\text { Universities and Colleges teaching } \\
\text { agriculture and NRM; CGIAR, } \\
\text { Investors }\end{array}$ & $\begin{array}{l}\text { oiofuel } \\
\text { ed }\end{array}$ \\
\hline \multicolumn{4}{|c|}{ Effective agricultural institutions } \\
\hline $\begin{array}{l}\text { Encourage the development of } \\
\text { institutional arrangements that link } \\
\text { tertiary agricultural education with } \\
\text { the communities they serve }\end{array}$ & $\begin{array}{l}\text { Medium } \\
\text { to long- } \\
\text { term }\end{array}$ & $\begin{array}{l}\text { Policy makers at the local, country } \\
\text { and regional levels; Universities } \\
\text { and Colleges teaching agriculture } \\
\text { and NRM; NARIs; CGIAR. }\end{array}$ & $\begin{array}{l}\text { The perception of the relevance } \\
\text { of the Universities and colleges } \\
\text { from the stakeholders } \\
\text { perspective will be enhanced }\end{array}$ \\
\hline Encourage the development of & Medium & Policy makers at the local and & This will ensure continuity of \\
\hline
\end{tabular}

${ }^{1}$ Short-term is $0-5$ years, medium-term is $5-10$ years and long term is beyond 10 years. 


\begin{tabular}{|c|c|c|c|}
\hline $\begin{array}{l}\text { institutional arrangements that } \\
\text { stem emigration of staff members }\end{array}$ & $\begin{array}{l}\text { to long } \\
\text { term }\end{array}$ & $\begin{array}{l}\text { country levels; Universities and } \\
\text { Colleges teaching agriculture and } \\
\text { NRM }\end{array}$ & $\begin{array}{l}\text { institutional management and } \\
\text { programmes offered and } \\
\text { provide room for expansion. }\end{array}$ \\
\hline $\begin{array}{l}\text { Promote institutional networking } \\
\text { within SSA and also worldwide } \\
\text { focusing on climate change and } \\
\text { other emerging issues }\end{array}$ & $\begin{array}{l}\text { Medium } \\
\text { to long } \\
\text { term }\end{array}$ & $\begin{array}{l}\text { Universities and Colleges teaching } \\
\text { agriculture and NRM; Investors; } \\
\text { NARIs; CGIAR. }\end{array}$ & $\begin{array}{l}\text { This will leverage on capacity } \\
\text { available within the network for } \\
\text { the benefit of the institutions }\end{array}$ \\
\hline $\begin{array}{lrr}\text { Encourage } & \text { inter- } & \text { and } \\
\text { multidisciplinary approaches } & \text { to } \\
\text { tertiary agricultural education } & \\
\end{array}$ & $\begin{array}{l}\text { Short } \\
\text { term }\end{array}$ & $\begin{array}{l}\text { s teaching } \\
\text { vate sector }\end{array}$ & $\begin{array}{l}\text { The graduates will develop } \\
\text { capacity for integrative thinking }\end{array}$ \\
\hline $\begin{array}{l}\text { Promote the development of } \\
\text { sustainable mechanisms for funding } \\
\text { tertiary agricultural institutions. }\end{array}$ & $\begin{array}{l}\text { Medium } \\
\text { to long } \\
\text { term }\end{array}$ & $\begin{array}{l}\text { Policy makers at the local, country } \\
\text { and regional levels; Governments; } \\
\text { Universities and Colleges teaching } \\
\text { agriculture and NRM; African } \\
\text { regional organisations (AU, FARA } \\
\text { etc) }\end{array}$ & $\begin{array}{l}\text { Could enable institutions } \\
\text { embark on for example, } \\
\text { experiential learning and } \\
\text { incorporate practical } \\
\text { entrepreneurship skills to their } \\
\text { students. }\end{array}$ \\
\hline $\begin{array}{l}\text { Ensure that students studying } \\
\text { agriculture and natural resources } \\
\text { management have a vocation in } \\
\text { those areas. }\end{array}$ & $\begin{array}{l}\text { Short to } \\
\text { medium } \\
\text { term }\end{array}$ & $\begin{array}{l}\text { Governments; Universities and } \\
\text { Colleges teaching agriculture and } \\
\text { NRM; African Regional } \\
\text { Organisations. }\end{array}$ & $\begin{array}{l}\text { Ensures value for money on } \\
\text { investment in training }\end{array}$ \\
\hline
\end{tabular}




\section{Conclusions}

It is recognised that although tertiary agricultural educational institutions in SSA are expected to advise on solutions to the climate change challenges facing the continent, in their present state these institutions are ill-equipped to move with speed to address these issues. There is currently an urgent need to integrate climate change into the curricula whether as a full-fledged course or as a component within other courses. The graduates of tertiary agricultural education need to have a full grasp of the science of climate change and its implications on the livelihoods of the communities they will be serving. Equipped with the necessary knowledge, the graduates will be able to advise on adaptation and mitigation strategies depending on situation. The graduates will also be able to contribute to the research needs on climate change so that the knowledge base in this area is expanded. At global, regional and local levels, aspects which are key to tackling climate change challenges are those to do with knowledge management; policy and international dialogue, local level implementation and national planning and financing. These need to be streamlined to strengthen the African voice in international environmental negotiations.

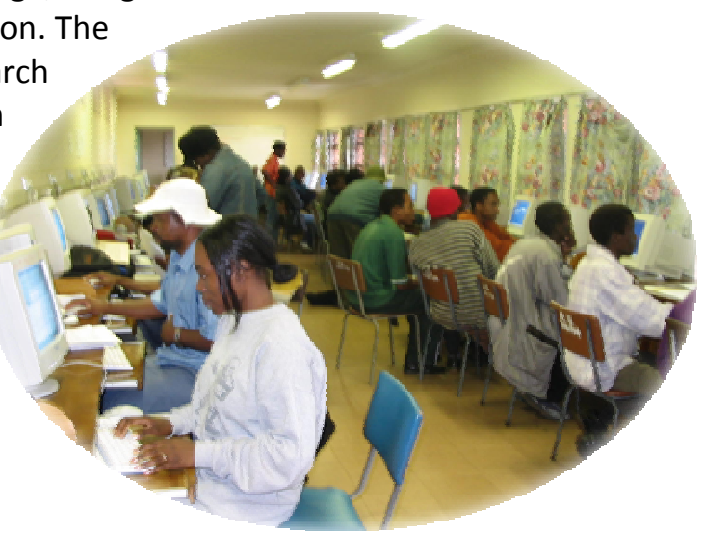

"Tertiary agricultural education objective must be to produce graduates who are technologically competent and relevant, equipped with the necessary "soft skills" and business skills and able to work with local, especially rural communities" 


\section{Literature Cited}

BASIC, 2006. Building Africa's Scientific and Institutional Capacity for Agriculture and Natural Resources. An ANAFE publication, $12 \mathrm{pp}$.

Bloom, D., D. Canning and K. Chan. 2005. Higher Education and Economic Development in Africa. World Bank Report. 85 pp. Available at: http://siteresources.worldbank.org/EDUCATION/Resources/2782001099079877269/547664-1099079956815/HigherEd_Econ_Growth_Africa.pdf

CBD. 2000. Convention on Biological Diversity 1996. COP 5 Decision V/5. http://www.cbd.int/decisions/cop-05.shtml?m=COP-05\&id=7147\&lg=0 Accessed 22.09.08

Chakeredza, S., A.B. Temu, J.D.K. Saka, D.C. Munthali, K. Muir-Leresche, F.K. Akinnifesi, O.C. Ajayi and G. Sileshi, 2008. Tailoring tertiary agricultural education for sustainable development in Sub-Saharan Africa: Opportunities and Challenges. Scientific Research Essay Vol 3(8): 326332.

Diao, X., P. Hazell, D. Resnick and J. Thurlow. 2006. The role of agriculture in development: Implications for Sub-Saharan Africa. IFPRI, Development strategy and Governance Division, Discussion Paper No 29. Available at: http://www.ifpri.org. Accessed on 20.09.08.

Jumbe, C.B.L. and F. Msiska, 2008. Bioenergy and development in sub-Saharan Africa: Are the policies conducive. Paper presented at the 2nd ANAFE International Symposium on "Mainstreaming Climate Change into Agricultural and Natural Resources Management Education: Tools, Experiences and Challenges" Held at Capital Hotel Lilongwe, Malawi from the 28th July to 1st August 2008.

Kandji, S.T., Verchot, L. and J. Mackensen, 2006. Climate change and variability in Southern Africa: Impacts and Adaptation in the Agricultural Sector. Published by UNEP and ICRAF, $36 \mathrm{pp}$.

MEA (2005). Millennium Ecosystems Assessment Synthesis Report: Strengthening Capacity to Manage Ecosystems sustainably for human well-being. Available at http://www.millenniumecosystmassessment.org Accessed on 20.09.08.

Rudebjer P., J. Baidu-Forson, B. Van Schagen, A. Jarvis, C. Staver and T. Hodgkin, 2008. Agrobiodiversity and climate change: what do students need to know? Paper presented at the 2nd ANAFE International Symposium on "Mainstreaming Climate Change into Agricultural and Natural Resources Management Education: Tools, Experiences and Challenges" Held at Capital Hotel Lilongwe, Malawi from the 28th July to 1st August 2008.

Rudebjer, P., A.B. Temu and J. Kung'u, 2005. Developing Agroforestry Curricula: a practical guide for academic institutions in Africa and Asia. Bogor, World Agroforestry Centre. $53 \mathrm{pp}$.

Saka, A. 2008. Global warming and the impacts of climate change on vulnerable communities and sectors of economic growth. Paper presented at the 2nd ANAFE International Symposium on "Mainstreaming Climate Change into Agricultural and Natural Resources Management Education: Tools, Experiences and Challenges" Held at Capital Hotel Lilongwe, Malawi from the 28th July to 1 st August 2008.

Schneider, S. 2008. Geoengineering: Could we or should we make it work? In: Philosophical Transactions of the Royal Society. Theme "Geoscale engineering to avert dangerous climate change". Compiled by Brian Launder and Michael T. Thompson. Available at: http://journals.royalsociety.org/content/Int0676gI7302372/ Accessed on 18.09.08

Stern N. 2006. The economics of climate change: A review. Available at: http://www.hmtreasury.gov.uk/independent_reviews/stern_review_economics_climate_change/stern_revi ew_Report.cfm Accessed on 18.09.08.

Temu, A., I. Mwanje and K. Mogotsi. 2003. Improving Agriculture and Natural Resources Education in Africa: A stitch in Time. Nairobi, Kenya: World Agroforestry Centre (ICRAF).

Temu, A.B. and S. Chakeredza, 2008. Institutionalization challenges for climate change management. Paper presented at the 2nd ANAFE International Symposium on "Mainstreaming Climate 
Change into Agricultural and Natural Resources Management Education: Tools, Experiences and Challenges" Held at Capital Hotel Lilongwe, Malawi from the 28th July to 1st August 2008.

Van Zyl, W.H., J.F. Gorgens, M. Bloom, J.H. Knoetze and H. Von Blottnitz, 2008. Potential of bioenergy (biofuels) production in southern Africa. Paper presented at the 2nd ANAFE International Symposium on "Mainstreaming Climate Change into Agricultural and Natural Resources Management Education: Tools, Experiences and Challenges" Held at Capital Hotel Lilongwe, Malawi from the 28th July to 1st August 2008. 


\section{WORKING PAPERS IN THIS SERIES}

1. Agroforestry in the drylands of eastern Africa: a call to action

2. Biodiversity conservation through agroforestry: managing tree species diversity within a network of communitybased, nongovernmental, governmental and research organizations in western Kenya.

3. Invasion of prosopis juliflora and local livelihoods: Case study from the Lake Baringo area of Kenya

4. Leadership for change in farmers organizations: Training report: Ridar Hotel, Kampala, 29th March to 2nd April 2005.

5. Domestication des espèces agroforestières au Sahel : situation actuelle et perspectives

6. Relevé des données de biodiversité ligneuse: Manuel du projet biodiversité des parcs agroforestiers au Sahel

7. Improved land management in the Lake Victoria Basin: TransVic Project's draft report.

8. Livelihood capital, strategies and outcomes in the Taita hills of Kenya

9. Les espèces ligneuses et leurs usages: Les préférences des paysans dans le Cercle de Ségou, au Mali

10. La biodiversité des espèces ligneuses: Diversité arborée et unités de gestion du terroir dans le Cercle de Ségou, au Mali

11. Bird diversity and land use on the slopes of Mt. Kilimanjaro and the adjacent plains, Tanzania

12. Water, women and local social organization in the Western Kenya Highlands

13. Highlights of ongoing research of the World Agroforestry Centre in Indonesia

14. Prospects of adoption of tree-based systems in a rural landscape and its likely impacts on carbon stocks and farmers' welfare: The FALLOW

Model Application in Muara Sungkai, Lampung, Sumatra, in a 'Clean Development Mechanism' context

15. Equipping integrated natural resource managers for healthy Agroforestry landscapes.

16. Are they competing or compensating on farm? Status of indigenous and exotic tree species in a wide range of agro-ecological zones of Eastern and Central Kenya, surrounding Mt. Kenya.

17. Agro-biodiversity and CGIAR tree and forest science: approaches and examples from Sumatra.

18. Improving land management in eastern and southern Africa: A review of policies.

19. Farm and household economic study of Kecamatan Nanggung, Kabupaten Bogor, Indonesia: A socio-economic base line study of Agroforestry innovations and livelihood enhancement.

20. Lessons from eastern Africa's unsustainable charcoal business.

21. Evolution of RELMA's approaches to land management: Lessons from two decades of research and development in eastern and southern Africa Participatory watershed management: Lessons from RELMA's work with farmers in eastern Africa. Strengthening farmers' organizations: The experience of RELMA and ULAMP.

Promoting rainwater harvesting in eastern and southern Africa.

The role of livestock in integrated land management.

Status of carbon sequestration projects in Africa: Potential benefits and challenges to scaling up.

Social and Environmental Trade-Offs in Tree Species Selection: A Methodology for Identifying Niche Incompatibilities in Agroforestry [Appears as AHI Working Paper no. 9]

28. Managing tradeoffs in agroforestry: From conflict to collaboration in natural resource management. [Appears as AHI Working Paper no. 10]

29. Essai d'analyse de la prise en compte des systemes agroforestiers pa les legislations forestieres au Sahel: Cas du Burkina Faso, du Mali, du Niger et du Senegal.

30. Etat de la recherche agroforestière au Rwanda etude bibliographique, période 1987-2003

31. Science and technological innovations for improving soil fertility and management in Africa: A report for NEPAD's Science and Technology Forum.

32. Compensation and rewards for environmental services.

33. Latin American regional workshop report compensation.

34. Asia regional workshop on compensation ecosystem services.

35. Report of African regional workshop on compensation ecosystem services.

36. Exploring the inter-linkages among and between compensation and rewards for ecosystem services CRES and human well-being

37. Criteria and indicators for environmental service compensation and reward mechanisms: realistic, voluntary, conditional and pro-poor 
The conditions for effective mechanisms of compensation and rewards for environmental services. Organization and governance for fostering Pro-Poor Compensation for Environmental Services. How important are different types of compensation and reward mechanisms shaping poverty and ecosystem services across Africa, Asia \& Latin America over the Next two decades?

Risk mitigation in contract farming: The case of poultry, cotton, woodfuel and cereals in East Africa. The RELMA savings and credit experiences: Sowing the seed of sustainability Yatich J., Policy and institutional context for NRM in Kenya: Challenges and opportunities for Landcare. Nina-Nina Adoung Nasional di So! Field test of rapid land tenure assessment (RATA) in the Batang Toru Watershed, North Sumatera.

Is Hutan Tanaman Rakyat a new paradigm in community based tree planting in Indonesia? Socio-Economic aspects of brackish water aquaculture (Tambak) production in Nanggroe Aceh Darrusalam. Farmer livelihoods in the humid forest and moist savannah zones of Cameroon.

Domestication, genre et vulnérabilité : Participation des femmes, des Jeunes et des catégories les plus pauvres à la domestication des arbres agroforestiers au Cameroun.

Land tenure and management in the districts around Mt Elgon: An assessment presented to the Mt Elgon ecosystem conservation programme.

The production and marketing of leaf meal from fodder shrubs in Tanga, Tanzania: A pro-poor enterprise for improving livestock productivity.

Buyers Perspective on Environmental Services (ES) and Commoditization as an approach to liberate ES markets in the Philippines.

Towards Towards community-driven conservation in southwest China: Reconciling state and local perceptions. Biofuels in China: An Analysis of the Opportunities and Challenges of Jatropha curcas in Southwest China. Jatropha curcas biodiesel production in Kenya: Economics and potential value chain development for smallholder farmers

Livelihoods and Forest Resources in Aceh and Nias for a Sustainable Forest Resource Management and Economic Progress

Agroforestry on the interface of Orangutan Conservation and Sustainable Livelihoods in Batang Toru, North Sumatra.

Assessing Hydrological Situation of Kapuas Hulu Basin, Kapuas Hulu Regency, West Kalimantan. Assessing the Hydrological Situation of Talau Watershed, Belu Regency, East Nusa Tenggara. Kajian Kondisi Hidrologis DAS Talau, Kabupaten Belu, Nusa Tenggara Timur. Kajian Kondisi Hidrologis DAS Kapuas Hulu, Kabupaten Kapuas Hulu, Kalimantan Barat. Lessons learned from community capacity building activities to support agroforest as sustainable economic alternatives in Batang Toru orang utan habitat conservation program (Martini, Endri et al.) Mainstreaming Climate Change in the Philippines. A Conjoint Analysis of Farmer Preferences for Community Forestry Contracts in the Sumber Jaya Watershed, Indonesia.

The highlands: a shared water tower in a changing climate and changing Asia Eco-Certification: Can It Deliver Conservation and Development in the Tropics.

Designing ecological and biodiversity sampling strategies. Towards mainstreaming climate change in grassland management.

Towards mainstreaming climate change in grassland management policies and practices on the Tibetan Plateau

An Assessment of the Potential for Carbon Finance in Rangelands

ECA Trade-offs Among Ecosystem Services in the Lake Victoria Basin.

The last remnants of mega biodiversity in West Java and Banten: an in-depth exploration of RaTA (Rapid Land Tenure Assessment) in Mount Halimun-Salak National Park Indonesia

Le business plan d'une petite entreprise rurale de production et de commercialisation des plants des arbres locaux. Cas de quatre pépinières rurales au Cameroun.

Les unités de transformation des produits forestiers non ligneux alimentaires au Cameroun. Diagnostic technique et stratégie de développement Honoré Tabuna et Ingratia Kayitavu.

Les exportateurs camerounais de safou (Dacryodes edulis) sur le

marché sous régional et international. Profil, fonctionnement et stratégies de développement. 
73. Impact of the Southeast Asian Network for Agroforestry Education (SEANAFE) on agroforestry education capacity.

74. Setting landscape conservation targets and promoting them through compatible land use in the Philippines.

75. Review of methods for researching multistrata systems.

76. Study on economical viability of Jatropha curcas L. plantations in Northern Tanzania Assessing farmers' prospects via cost-benefit analysis

77. Cooperation in Agroforestry between Ministry of Forestry of Indonesia and International Center for Research in Agroforestry

78. "China's bioenergy future. an analysis through the Lens if Yunnan Province

79. Land tenure and agricultural productivity in Africa: A comparative analysis of the economics literature and recent policy strategies and reforms

80. Boundary organizations, objects and agents: linking knowledge with action in agroforestry watersheds

81. Reducing emissions from deforestation and forest degradation (REDD) in Indonesia: options and challenges for fair and efficient payment distribution mechanisms

82. Mainstreaming Climate Change into Agricultural Education: Challenges and Perspectives 
The World Agroforestry Centre is an autonomous, non-profit research organization whose vision is a rural transformation in the developing world where smallholder households strategically increase their use of trees in agricultural landscapes to improve their food security, nutrition, income, health, shelter, energy resources and environmental sustainability. The Centre generates science-base knowledge about the diverse role that trees play in agricultural landscapes, and uses its research to advance policies and practices that benefit the poor and the environment.

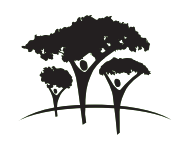

